\section{Hemilabile 配位子}

$\left(2-\mathrm{MeOC}_{6} \mathrm{H}_{4}\right) \mathrm{PPh}_{2}$ や $\left(2-\mathrm{Me}_{2} \mathrm{NC}_{6} \mathrm{H}_{4}\right) \mathrm{PPh}_{2}$ には, ソフ 卜な配位性基 $\left(\mathrm{PPh}_{2}\right)$ とハードな配位性基 $\left(\mathrm{MeO}, \mathrm{Me}_{2} \mathrm{~N}\right)$ とがあり, ソフトなルイス酸である低酸化状態の後期遷 移金属に対し，前者は安定な配位結合を形成し，後者は 配位解離の平衡を起こす。1979 年にJeffreyと Rauchfuss は，上記の配位子が示すこの挙動に hemilabile の用語を 提案した。この言葉は「(分子の)半分 (hemi=half)が解 離しやすい(labile)」を意味し, 当初は二座配位子を対象 としたものであったが，現在では特性の異なる 2 種類以 上の配位性基をもち，配位性基の一部が容易に解離平衡 を起こす多座配位子に幅広く適用されている。

Hemilabile 配位子は遷移金属に配位したまま配位子の 一部を解離するため, 錯体の安定性を担保しつつ価電子 数を減ずることができる。配位様式の変化により供与電 子数を減らす配位子としてインデニル配位子 $\left(\eta^{5} \rightarrow \eta^{3}\right)$ やニトロシル配位子(直線形 $\rightarrow$ 屈曲形) が知られている が，これらの配位子に hemilabile の用語は用いない。価 電子数が減少した配位不飽和錯体は反応基質を配位しゃ すく，高い反応性を発現しやすいため，高活性触媒の開 発などに利用されている。

(小澤文幸)

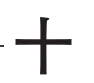

\section{ビニロガス向山アルドール反応}

シリルエノールエーテルをルイス酸存在下にてアルデ ヒドと反応させる向山アルドール反応に対し，ビニロガ ス向山アルドール反応では, シリルジエノールエーテル をルイス酸存在下でアルデヒドと反応させる。シリルジ エノールエーテルは， $\alpha, \beta$-不飽和カルボニル化合物の $\gamma$ 位のプロトンもしくは $\beta, \gamma$-不飽和カルボニル化合物の $\alpha$

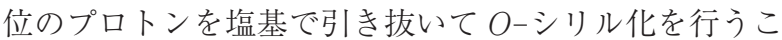
とによって合成される。 $\mathrm{Na}^{+}$などの金属が対カチオンに なったジエノラートでは $\alpha$ 位でアルドール反応が起こ るが，シリル基が共有結合で付いたシリルジエノール エーテルでは主に $\gamma$ 位 (ジエン末端)で反応が進行し, $\delta-$ ヒドロキシ $-\alpha, \beta$-不飽和カルボニル化合物を与える。ビ ニロガス向山アルドール反応ではキラルなリガンドが付 いたルイス酸触媒を使う不斉反応も検討されている。 $\alpha, \beta$-不飽和カルボニルや $\gamma-$ ラクトンなどの大きな構造 を導入することができるため，多段階合成において工程 数の削減に貢献する。

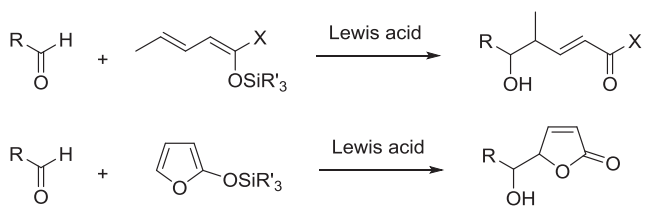

(細川誠二郎)

\section{イサチン}

イサチン(インドリン-2,3-ジオン，または $1 H$-イン ドール-2,3-ジオン)は，インドールに由来する母骨格に $\alpha$-ケトアミド構造が組み込まれたへテロ環化合物であ る。イサチンは, 求電子性の高い C3 位カルボニル基へ の求核付加, C5 位や C7 位への芳香族求電子置換, $\mathrm{N}$ 原子での求核置換，官能基選択的な還元，スピロ環化な どの反応が進行する。このような, 多岐に渡る変換反応 が適用可能であることから，イサチンは官能基化された 多様な 2-オキシインドール誘導体の前駆体として極め て重要である。またイサチンは，キノリンやキナゾリ ン, インドール, ピロリジノインドリンなどのへテロ環 骨格の合成のビルディングブロックとしても広く利用さ れている。
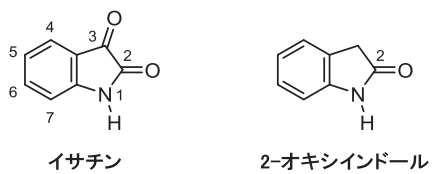

（中崎敦夫）

\section{エラジタンニン類}

「皮なめし(tanning)」を語源とするタンニン類は, 分 子量が500-3,000 程度の植物ポリフェノール成分であ り，タンパク質などの生体成分と強い親和性を示す。そ れらは化学構造上の特徵から, 縮合型と加水分解性に大 別され，エラジタンニンはそのうち加水分解性タンニン に分類される。加水分解性夕ンニンは, 糖の複数の水酸 基に没食子酸がエステル結合することによって形成され る。加水分解によって糖と没食子酸のみを生じる化合物 群をガロタンニンと呼び，エラグ酸を生じるものをエラ ジタンニンと称する。

エラジタンニンは, ガロタンニンの没食子酸部分が分 子内で酸化的に炭素-炭素結合を形成することで生合成 されると考えられている。この際, 生じる没食子酸の二 量体構造はHHDP (hexahydroxydiphenoyl) 基と呼ばれ る。また, 分子間の没食子酸単位で炭素-酸素結合を繰 り返してオリゴマーを形成しているものもある。HHDP 基がさらに酸化されたデヒドロエラジタンニンや, 糖の アノマー位置と HHDP 基の芳香環炭素とが結合した C配糖体型，さらにそれにカテキン構造が結合した複合型 など多種多様な構造を持つエラジタンニン類が知られて いる。

(阿部 仁) 